\title{
Invasive mangroves produce unsuitable habitat for endemic goby and burrowing shrimp pairs in Kāne'ohe Bay, $\mathrm{O}^{`} \mathrm{ahu}$, Hawai'i
}

\section{Los manglares invasores producen hábitats inadecuados para las parejas de góbidos endémicos y camarones excavadores en la bahía de Kāne‘ohe, O`ahu, Hawai'i}

\author{
Mandy Hansen ${ }^{1 *}$, Karen D Crow ${ }^{1}$, Margot V Buchbinder ${ }^{2}$, Katharyn E Boyer ${ }^{2}$ \\ 1 Department of Biology, San Francisco State University, 1600 Holloway Avenue, San Francisco, California \\ 94132, USA \\ 2 Estuary \& Ocean Science Center, San Francisco State University, 3150 Paradise Drive, Tiburon, California \\ 94920, USA
}

* Corresponding author. E-mail: mhansen2@mail.sfsu.edu

\begin{abstract}
Hawai'ian ecosystems evolved in relative isolation and support an abundance of native and endemic species. As such, they are particularly vulnerable to introduced species that alter habitat and interfere with species interactions. Although mangroves are valued globally for shoreline protection and other services, their invasion of the Hawai'ian islands may have negative effects on the abundance and functions of native species. On an island in Kāne'ohe Bay, O'ahu, we explored the relationship between invasion of the red mangrove, Rhizophora mangle, and abundance of the native burrowing shrimp Alpheus rapax, which shares its burrows with the endemic goby Psilogobius mainlandi in a mutualism that reduces predation on both. We hypothesized that the abundance of shrimp/goby burrows is reduced beneath mangroves due to increased cover associated with mangrove prop roots, which trap leaves and debris and may harbor the invasive red alga Gracilaria salicornia. At 3 mangrove-invaded sites, we conducted a survey of burrow density and benthic debris and found $\sim 4-5 \times$ lower burrow density and $4 \times$ greater cover of debris under the mangrove edge compared to sandflats that were 1.5 and $5.0 \mathrm{~m}$ away. Burrow density was negatively correlated with total cover of benthic debris and with subgroups of that cover composed of G. salicornia or leaves. We tested the effect of debris removal over 2 weeks, which resulted in 3-8× more burrows. Thus, we provide evidence that invasive red mangroves, through trapping leaves and promoting presence of invasive G. salicornia among their prop roots, have strong negative effects on shrimp/goby burrow density. Although our study was limited in spatial scope, we propose that current efforts to remove mangroves in Hawai' $\mathrm{i}$, for both cultural and ecological reasons, will mitigate negative effects on endemic goby and native shrimp habitat.
\end{abstract}

Key words: mangrove, Rhizophora mangle, Gracilaria salicornia, invasive, Hawai‘i.

RESUMEN. Los ecosistemas hawaianos evolucionaron en aislamiento relativo y sostienen una abundancia de especies nativas y endémicas. Como tal, son particularmente vulnerables a las especies introducidas que alteran el hábitat e interfieren con las interacciones entre especies. Aunque los manglares son valorados globalmente por la protección a la costa y otros servicios, su invasión de las islas hawaianas podría tener efectos negativos sobre la abundancia y las funciones de las especies nativas. En una isla en la bahía de Kāne‘ohe, O‘ahu, exploramos la relación entre la invasión del mangle rojo, Rhizophora mangle, y la abundancia del camarón excavador nativo Alpheus rapax, que comparte sus madrigueras con el góbido endémico Psilogobius mainlandi en un mutualismo que reduce la depredación de ambos. Presumimos que la abundancia de madrigueras de camarones y góbidos disminuye debajo de los manglares debido a la mayor cobertura asociada con las raíces de los manglares, que atrapan las hojas y los escombros y pueden albergar al alga roja invasiva Gracilaria salicornia. En 3 sitios invadidos por manglares, realizamos un estudio de la densidad de madrigueras y los escombros bentónicos y encontramos $\sim 4-5 \times$ menor densidad de madrigueras y $4 \times$ más cobertura de escombros debajo del borde del manglar en comparación con los fondos arenosos que estaban a 1.5 y $5.0 \mathrm{~m}$ de distancia. La densidad de madrigueras se correlacionó negativamente con la cobertura de escombros bentónicos total, así como con los subgrupos de esa cobertura compuestos por G. salicornia u hojas. Probamos el efecto de la remoción de escombros durante 2 semanas, lo que resultó en 3-8× más madrigueras. Por lo tanto, proporcionamos evidencia de que los manglares rojos invasores, al atrapar las hojas entre sus raíces fúlcreas y facilitar la presencia del alga invasiva $G$. salicornia, tienen fuertes efectos negativos en la densidad de madrigueras de camarones y góbidos. Aunque nuestro estudio tuvo un alcance espacial limitado, proponemos que los esfuerzos actuales para eliminar los manglares en Hawai' $i$, tanto por razones culturales como ecológicas, mitigarán los efectos negativos sobre el hábitat endémico del camarón y del góbido

Palabras clave: manglar, Rhizophora mangle, Gracilaria salicornia, invasivo, Hawai‘i.

\section{INTRODUCTION}

Human-mediated introduction of species to new geographic locations is an unprecedented and unique form of

\section{INTRODUCCIÓN}

La introducción de especies en nuevas zonas geográficas mediada por humanos es una forma de cambio global 
global change (Ricciardi 2007). For the majority of these introductions, impacts have not been quantified, challenging our understanding of the consequences of invasion and complicating management decisions (Blackburn et al. 2014, Jeschke et al. 2014). However, some generalizations have emerged over several decades of synthesis, including that introduced species performing a novel function within the invaded locale often produce the greatest impacts (Parker et al. 1999, Simberloff 2011). This is because the distinctiveness of the invader's traits leads to novel resource use or changes in habitat structure that fundamentally change the invaded system (reviewed by Kumschick et al. 2015). For example, plants that colonize intertidal mud or sandflats are a category of invasive species that are considered "transformers," i.e., the $\sim 10 \%$ of invading plant taxa that have clear ecosystem impacts through wholesale changes to the character, condition, form or nature of ecosystems over substantial areas (Richardson et al. 2000).

The Hawai'ian islands are among the world's marine invasion hotspots, with a high proportion of harmful invaders (Molnar et al. 2008), including a sandflat "transformer", the red mangrove, Rhizophora mangle. This mangrove species was introduced from Florida to Hawai'i in 1902 to help stabilize shorelines around the island of Moloka' $i$. Since their introduction, mangroves have spread rapidly, colonizing vast areas across the archipelago (Chimner et al. 2006) and causing habitat loss for native birds including the Hawai'ian duck (Anas wyvilliana), Hawai'ian coot (Fulica alai), Hawai'ian stilt (Himantopus mexicanus knudseni), and common moorhen (Gallinula chloropus sandvicensis), which find the mangroves unsuitable for foraging and nesting (Allen 1998). Instead, Hawai'ian mangroves provide habitat for invasive species such as the cattle egret (Bubulcus ibis), which feeds on the chicks of native birds (Allen 1998). In general, Hawai'ian mangroves appear to be underutilized ecologically (Walsh 1967); for example, Hawai'ian sediment invertebrates do not consume mangrove detritus as in the mangrove's native range, likely because they have not evolved to consume the tannin-rich leaves, which are unpalatable and/or toxic to some species (Demopoulos et al. 2007). However, these mangroves have created novel habitat through increased detritus deposition (exceptionally high in Hawai'i) (Allen 1998, Cox and Allen 1999) and accumulation of finer sediments and organic matter, shifting the community to subsurface deposit feeders not found on nearby sandflats (Demopoulos and Smith 2010). Further, introduced shrimp, fish, and crabs have all been identified within this new habitat (Nakahara 2007), and the mangrove's prop roots support at least 6 species of introduced barnacles and sponges (Demopoulos and Smith 2010). These mangrove prop roots may also provide a substratum on which the red alga Gracilaria salicornia can attach and grow or may trap drifting mats (authors' personal observations). Gracilaria salicornia was introduced to the state sometime before 1946 and collected from the island of Hawai'i for única y sin precedentes (Ricciardi 2007). Para la mayoría de estas introducciones, los impactos no han sido cuantificados, lo que obstaculiza nuestra comprensión de las consecuencias de la invasión y complica las decisiones de gestión (Blackburn et al. 2014, Jeschke et al. 2014). Sin embargo, han surgido algunas generalizaciones a lo largo de varias décadas de síntesis, incluso que las especies introducidas que desempeñan una nueva función dentro del sitio invadido suelen producir los mayores impactos (Parker et al. 1999, Simberloff 2011). Esto se debe a que las particularidades distintivas de las características del invasor conducen a un uso novedoso de los recursos o a cambios en la estructura del hábitat que modifican fundamentalmente el sistema invadido (revisado por Kumschick et al. 2015). Por ejemplo, las plantas que colonizan el lodo intermareal o las planicies arenosas son una categoría de especies invasoras que se consideran "transformadoras", i.e., el $\sim 10 \%$ de los taxones de plantas invasoras que tienen impactos claros en el ecosistema a través de cambios drásticos en el carácter, la condición, la forma o la naturaleza de los ecosistemas en áreas sustanciales (Richardson et al. 2000).

Las islas hawaianas se encuentran entre los puntos críticos de invasiones marinas del mundo, con una alta proporción de invasores dañinos (Molnar et al. 2008), incluido un "transformador" de planicies arenosas, el mangle rojo, Rhizophora mangle. Esta especie de manglar se introdujo desde Florida a Hawai'i en 1902 para ayudar a estabilizar las costas alrededor de la isla de Moloka'i. Desde su introducción, los manglares se han extendido rápidamente $\mathrm{y}$, desde entonces, han colonizado vastas áreas en todo el archipiélago (Chimner et al. 2006) y causado la pérdida del hábitat de aves nativas, como el pato de Hawai'i (Anas wyvilliana), la focha hawaiana (Fulica alai), la monjita americana (Himantopus mexicanus knudseni) y la gallineta común (Gallinula chloropus sandvicensis), las cuales son incapaces de utilizar los manglares para alimentarse o para anidar (Allen 1998). En cambio, los manglares hawaianos proporcionan hábitat para especies invasoras como la garza ganadera (Bubulcus ibis), que se alimenta de los polluelos de aves nativas (Allen 1998). En general, los manglares hawaianos parecen estar infrautilizados ecológicamente (Walsh 1967); por ejemplo, los invertebrados sedimentarios hawaianos no consumen los detritos de los manglares como en el área de distribución nativa del manglar, probablemente porque no han evolucionado para consumir las hojas ricas en taninos, las cuales son desagradables y/o tóxicas para algunas especies (Demopoulos et al. 2007). Sin embargo, estos manglares han creado un hábitat nuevo al aumentar la deposición de detritos (excepcionalmente alta en Hawai'i) (Allen 1998, Cox y Allen 1999) y la acumulación de sedimentos más finos y materia orgánica, lo cual ha cambiado la comunidad a detritívoros subsuperficiales que no habitan en las planicies arenosas cercanas (Demopoulos y Smith 2010). Además, se han identificado camarones, peces y cangrejos introducidos dentro de este nuevo hábitat (Nakahara 2007), y las raíces 
Hansen et al.: Invasive mangroves reduce habitat for Hawai'ian shrimp and goby pairs

use in aquaculture on $\mathrm{O}^{\text {'ahu }}$ and subsequently on Moloka' $\mathrm{I}$ (Smith et al. 2002, Smith et al. 2004). This alga can form mats up to $2 \mathrm{~m}$ across (Larned 1998), affecting the food web through its relative unpalatability and habitat degradation for reef fishes and corals (Smith et al. 2004, Williams and Smith 2007). Red mangroves were introduced to the island of O'ahu circa 1922 (Chimner et al. 2006) and the shores of Kāne'ohe Bay support some of the largest mangrove stands (Devaney et al. 1982).

The red mangrove stands interrupt shallow sandflats that are home to the endemic Hawai'ian shrimp goby Psilogobius mainlandi, which co-occurs in burrows with the native snapping shrimp Alpheus rapax (Langston and Spalding 2017). Other mutualistic shrimp/goby pairs are abundant throughout the Pacific, but $P$. mainlandi is the only shrimp-associated goby that occurs in Hawai' $i$ (Karplus and Thompson 2011). In this obligate mutualistic relationship (Karplus and Thompson 2011, Lyons 2013), the shrimp excavates a burrow and, because of its poor eyesight (Zeng and Jaafar 2012), relies on the goby to act as a lookout. The fish alerts the shrimp to potential predators with a flick of its tail, triggering both to retreat into the burrow (Hoover 2016). Small, cryptobenthic fishes, including gobies, comprise up to $60 \%$ of the consumed biomass in and around coral reefs, making these fishes a cornerstone of ecosystem functioning. Therefore, we expect factors affecting the abundance and distribution of the native shrimp/goby pairs in Hawai'i to likely have ripple effects through multiple trophic levels. However, to our knowledge the effects of red mangrove invasion on these species has not been examined.

We propose that mangroves invading Hawai'ian shorelines reduce habitat for the sandflat dwelling native shrimp and goby pairs. In places where G. salicornia has invaded, it may also contribute cover that interferes with shrimp/goby burrowing; this alga can grow either attached to substrata, in dense mats without anchorage points near the shore, or as loose thalli that dislodge and become trapped in depressions (Nelson et al. 2009). The potential for mangroves to trap and promote growth of G. salicornia is a concern for nearby coral reefs as well, as spread of this alga can lead to smothering and killing of coral (Smith et al. 2004).

We conducted a field survey to estimate density of shrimp/goby burrows, percent cover of benthic debris, and composition of this debris along mangrove-invaded shores of a small island in Kāne'ohe Bay, O'ahu. Specifically, we hypothesized that shrimp/goby burrows are less abundant under mangroves than on nearby sandflats, and that burrow densities increase with distance from the mangrove edge. We predicted that burrow density would be negatively correlated with benthic cover, including G. salicornia and accumulated leaves. We also conducted a benthic debris removal experiment to evaluate whether numbers of shrimp/goby burrows quickly increase after debris removal; if so, this would suggest that accumulation of debris (perhaps including invasive aéreas del manglar sustentan al menos 6 especies de percebes y esponjas introducidas (Demopoulos y Smith 2010). Estas raíces aéreas de manglar también pueden proporcionar un sustrato sobre el cual el alga roja Gracilaria salicornia puede adherirse y crecer o el cual puede atrapar mantos a la deriva (observaciones personales de los autores). Gracilaria salicornia se introdujo en el estado en algún momento antes de 1946 y se recolectó en la isla de Hawai'i para su uso en acuacultura en O'ahu y posteriormente en Moloka'I (Smith et al. 2002, Smith et al. 2004). Esta alga puede formar mantos de hasta $2 \mathrm{~m}$ de ancho (Larned 1998), lo que afecta la red alimentaria debido a su relativa falta de palatabilidad y la degradación del hábitat de los peces de arrecife y los corales (Smith et al. 2004, Williams y Smith 2007). Los manglares rojos se introdujeron en la isla de O'ahu circa 1922 (Chimner et al. 2006), y las costas de la bahía de Kāne'ohe sustentan algunas de las rodales de manglares más grandes (Devaney et al. 1982).

Los rodales de mangle rojo interrumpen las planicies arenosas poco profundas que son el hogar del góbido camaronero endémico de Hawai'i Psilogobius mainlandi, que coexiste en madrigueras con el camarón pistola nativo Alpheus rapax (Langston y Spalding 2017). Otras parejas mutualistas de camarón/góbido abundan en todo el Pacífico, pero $P$. mainlandi es el único góbido asociado a camarones presente en Hawai'i (Karplus y Thompson 2011). En esta relación de mutualismo obligado (Karplus y Thompson 2011, Lyons 2013), el camarón excava una madriguera y, debido a su visión deficiente (Zeng y Jaafar 2012), depende del góbido para que actúe como vigía. El pez alerta al camarón sobre posibles depredadores con un golpe ligero de su cola, lo que provoca que ambos se retraigan a la madriguera (Hoover 2016). Los pequeños peces criptobentónicos, incluidos los góbidos, comprenden hasta el $60 \%$ de la biomasa consumida en los arrecifes de coral y sus alrededores, lo que los convierte en una piedra angular para el funcionamiento del ecosistema. Por lo tanto, esperamos que los factores que afectan la abundancia y la distribución de las parejas nativas de camarón/góbido en Hawai ‘ i probablemente desencadenen efectos a través de múltiples niveles tróficos. Sin embargo, hasta donde sabemos, no se han examinado los efectos de la invasión del mangle rojo en estas especies.

Proponemos que los manglares que invaden las costas de Hawai'i reducen el hábitat para las parejas nativas de camarones y góbidos que habitan en las planicies arenosas. En los lugares que ha invadido, G. salicornia también puede crear una cobertura que interfiere con la construcción de las madrigueras de camarones/góbidos; esta alga puede crecer ya sea adherida a sustratos, en densos mantos sin puntos de anclaje cerca de la costa, o como talos sueltos que se desprenden y quedan atrapados en depresiones (Nelson et al. 2009). El potencial de los manglares para atrapar y promover el crecimiento de G. salicornia también es una preocupación para los arrecifes de coral cercanos, ya que la propagación de 
G. salicornia) is a primary mechanism for reduced shrimp/ goby burrowing along the mangrove edge.

\section{MATERIALS AND METHODS}

\section{Survey of burrow density and benthic cover with distance from the mangroves}

We chose 3 study sites where mangroves were abundant next to sandy shrimp/goby habitat along the shores of Moku o Lo'e, at the Hawai'i Institute of Marine Biology (Fig. 1). Sites 1 and 2 were located in shallow lagoons with little to no coral nearby, while site 3 was located near a deeper lagoon with scattered coral heads in close proximity. A $25-\mathrm{m}$ transect tape was placed along the mangroves and the number of shrimp/goby burrows was counted every $5 \mathrm{~m}$ within a $0.25-\mathrm{m}^{2}$ quadrat that extended into the mangroves from the prop root edge. The quadrat could be opened in order to place it around prop roots when encountered. These burrow counts were repeated along 2 parallel transects on the adjacent sandflats at $1.5 \mathrm{~m}$ and $5.0 \mathrm{~m}$ from the mangrove edge. Within each quadrat, we first used the point-intercept method at 9 points to estimate percent benthic cover (following Karl et al. (2016), then gently lifted the debris to count burrows underneath. The types of cover evaluated were leaves, coral rubble, G. salicornia, no benthic debris (bare sand), or, rarely, "other cover". We also counted the prop roots within each quadrat under the mangroves. As our presence sometimes led to retreat of shrimp/goby pairs into their burrows, we counted all the burrows whether or not we saw the shrimp and gobies.

Analyses were conducted in R v.3.6.3 ( $\mathrm{R}$ Core Team 2020). Generalized linear models were used to evaluate the effects of site and distance from mangrove edge on measured variables. Burrow density was analyzed using a Poisson distribution, while percent cover metrics were logit-transformed to achieve homogeneity of variances and analyzed with a Gaussian distribution. Tukey tests were used to evaluate significant main effects using the multcomp package (Hothorn et al. 2008). We also evaluated the relationship between total percent cover of benthic debris (logit transformation) and burrow density $\left(\log _{10}+1\right)$ using a linear regression. The relationship of burrow density to both G. salicornia and leaf cover were evaluated separately using linear regressions with logit transformations of cover data.

\section{Debris removal experiment}

In order to determine if cover of benthic debris is a factor that affects the distribution of shrimp/goby burrows, we manipulated debris beneath the mangrove edge. After initially evaluating burrow density and percent cover of all material, we removed the loose or attached debris (primarily leaves and algae) within a $0.25-\mathrm{m}$ quadrat at 3 of the plots along the transects $(0,10$, and $20 \mathrm{~m})$ at all 3 sites. Additional material that accumulated in the plots was cleared every other day for esta alga puede provocar la asfixia y la muerte de los corales (Smith et al. 2004).

Realizamos un muestreo de campo para estimar la densidad de las madrigueras de camarones/góbidos, el porcentaje de cobertura de escombros bentónicos y la composición de estos escombros a lo largo de las costas invadidas por manglares de una pequeña isla en la bahía de Kāne'ohe, O‘ahu. Específicamente, planteamos la hipótesis de que las madrigueras de camarones/góbidos son menos abundantes debajo de los manglares que en las planicies arenosas cercanas, y que la densidad de las madrigueras aumenta con la distancia al borde del manglar. Predijimos que la densidad de las madrigueras se correlacionaría negativamente con la cobertura bentónica, incluida G. salicornia y hojas acumuladas. También realizamos un experimento de eliminación de escombros bentónicos para evaluar si el número de madrigueras de camarones/góbidos aumenta rápidamente después de la eliminación de escombros; de ser así, esto sugeriría que la acumulación de escombros (quizás con la especie invasora G. salicornia) es un mecanismo principal que reduce el establecimiento de madrigueras de camarones/góbidos a lo largo del borde del manglar.

\section{MATERIALES Y MÉTODOS}

\section{Muestreo de la densidad de madrigueras y la cobertura bentónica con respecto a la distancia de los manglares}

Elegimos 3 sitios de estudio donde abundaban los manglares junto al hábitat arenoso de los camarones/ góbidos a lo largo de las costas de Moku o Lo'e, en el Instituto de Biología Marina de Hawai'i (Fig. 1). Los sitios 1 y 2 estaban ubicados en lagunas someras con poco o ningún coral cerca, mientras que el sitio 3 estaba ubicado cerca de una laguna más profunda con cabezas de coral dispersas en las proximidades. Se colocó una cinta de transecto de $25 \mathrm{~m}$ a lo largo de los manglares y, cada $5 \mathrm{~m}$, se contó el número de madrigueras de camarones/góbidos que había dentro de un cuadrante de $0.25 \mathrm{~m}^{2}$ que se extendía hacia el interior de los manglares desde el borde de la raíces aéreas. El cuadrante se podía abrir para colocarlo alrededor de las raíces aéreas cuando se atravesaban. Estos conteos de madrigueras se repitieron en las planicies arenosas adyacentes a lo largo de 2 transectos paralelos a 1.5 y $5.0 \mathrm{~m}$ del borde del manglar. Dentro de cada cuadrante, primero usamos el método de puntos de intercepción en 9 puntos para estimar el porcentaje de cobertura bentónica siguiendo a Karl et al. (2016); posteriormente, levantamos suavemente los escombros para contar las madrigueras debajo. Los tipos de cobertura evaluados fueron hojas, escombros de coral, G. salicornia, sin restos bentónicos (arena sin vegetación) o, raras veces, "otra cobertura". También contamos las raíces aéreas dentro de cada cuadrante debajo de los manglares. Como nuestra presencia algunas veces provocó que las parejas de camarones/góbidos se retrajeran a sus madrigueras, 


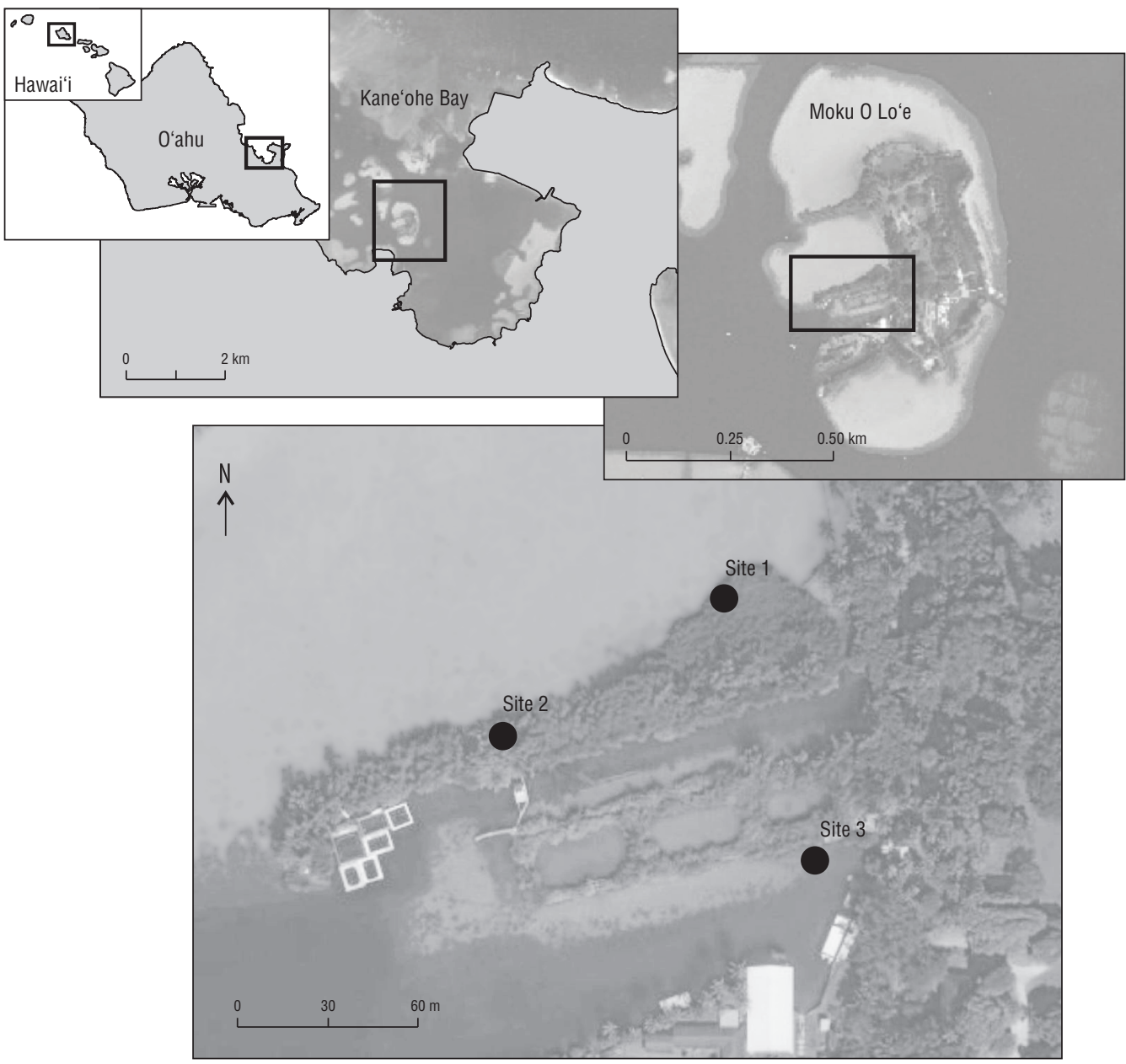

Figure 1. Map of study locations at the Hawai'i Institute of Marine Biology on Moku O Lo'e, Kāne‘ohe Bay, O‘ahu, Hawai‘i, USA. Site 1: $21^{\circ} 26^{\prime} 01.2^{\prime \prime} \mathrm{N}, 157^{\circ} 47^{\prime} 20.9^{\prime \prime} \mathrm{W}$; site $2: 21^{\circ} 25^{\prime} 59.7^{\prime \prime} \mathrm{N}, 157^{\circ} 47^{\prime} 23.4^{\prime \prime} \mathrm{W}$; and site $3: 21^{\circ} 25^{\prime} 58.4^{\prime \prime} \mathrm{N}, 157^{\circ} 47^{\prime} 20.1^{\prime \prime} \mathrm{W}$.

Figura 1. Mapa de los sitios de estudio en el Instituto de Biología Marina de Hawai`i en Moku O Lo‘e, bahía de Kāne‘ohe, O‘ahu, Hawai‘i,

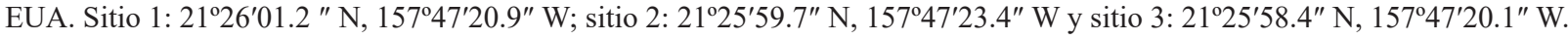

a 2-week period. After 2 weeks of maintaining cleared plots, burrow density was re-assessed. We evaluated the effects of time (before and after debris removal) and site as fixed factors and their interaction using a generalized linear model with a Poisson distribution.

\section{RESULTS}

\section{Distance from mangroves is associated with lower cover of debris and higher burrow density}

We found $\sim 4-5 \times$ lower densities of shrimp/goby burrows under the mangrove edge compared to either distance away on the adjacent sandflat (Fig. 2, Table 1; Tukey tests $P<0.0001$ for both sandflat distances). There were 11.6 burrows $\cdot \mathrm{m}^{-2}$ under the mangrove edge, compared to the 52.7 and 64.7 burrows $\cdot \mathrm{m}^{-2}$ at 1.5 and $5.0 \mathrm{~m}$ from the mangroves, respectively (Fig. 2); these sandflat burrow densities were somewhat different from each other (Tukey test, $P=$ contamos todas las madrigueras, se observaran o no camarones y góbidos.

Los análisis se realizaron en R v.3.6.3 (R Core Team 2020). Se utilizaron modelos lineales generalizados para evaluar los efectos del sitio y la distancia al borde del manglar sobre las variables medidas. La densidad de madrigueras se analizó utilizando una distribución de Poisson, mientras que para las métricas de cobertura porcentual se realizó una transformación logit para lograr la homogeneidad de las varianzas y se analizaron con una distribución gaussiana. Se utilizaron pruebas de Tukey para evaluar los efectos principales significativos utilizando el paquete multcomp (Hothorn et al. 2008). También evaluamos la relación entre el porcentaje total de cobertura de detritos bentónicos (transformación logit) y la densidad de madrigueras $\left(\log _{10}+1\right)$ mediante una regresión lineal. La relación de la densidad de madrigueras con la cobertura de G. salicornia y la cobertura de hojas se evaluó por separado usando regresiones lineales con transformaciones logit de los datos de cobertura. 
0.047). There was also a difference in burrow densities by site, with site 1 having greater densities than site 3 (Tukey test, $P=0.0238$ ) and site 2 having intermediate densities. The pattern of increasing burrow density with distance from the mangrove was consistent across sites (no interaction, Table 1).

Benthic debris cover consisted primarily of fallen leaves, G. salicornia, or rubble (coral skeletons or rock). Of all benthic debris cover observations, $48 \%$ were fallen mangrove leaves; therefore, benthic debris cover under the mangroves and in nearby sandflats was largely associated with mangroves per se. In addition, G. salicornia composed $28.7 \%$ of the total debris cover, while coral rubble and "other" cover made up $21.3 \%$ and $0.1 \%$ of the debris cover observations, respectively. Prop root density was variable and ranged from a mean of 12.7 roots $\cdot \mathrm{m}^{-2}(\mathrm{SD}=8.5)$ at site 2 to 16.7 roots $\cdot \mathrm{m}^{-2}(\mathrm{SD}=10.3)$ at site 1 to $27.3 \mathrm{roots} \cdot \mathrm{m}^{-2}(\mathrm{SD}=$ 19.2) at Site 3.

Total percent cover of benthic debris, which could exceed $100 \%$ if cover types were layered, was $\sim 4 \times$ higher under the mangrove edge compared to that on sandflats at $1.5 \mathrm{~m}$ and $5.0 \mathrm{~m}$ away (Fig. 3; Tukey tests, $P<0.0001$ for both distances). Benthic debris cover reached $66 \%$ under the mangrove edge ( $75 \%$ total cover with layering) and was composed of leaves, algae, and other debris. The adjacent sandflats exhibited significantly less cover of debris, with

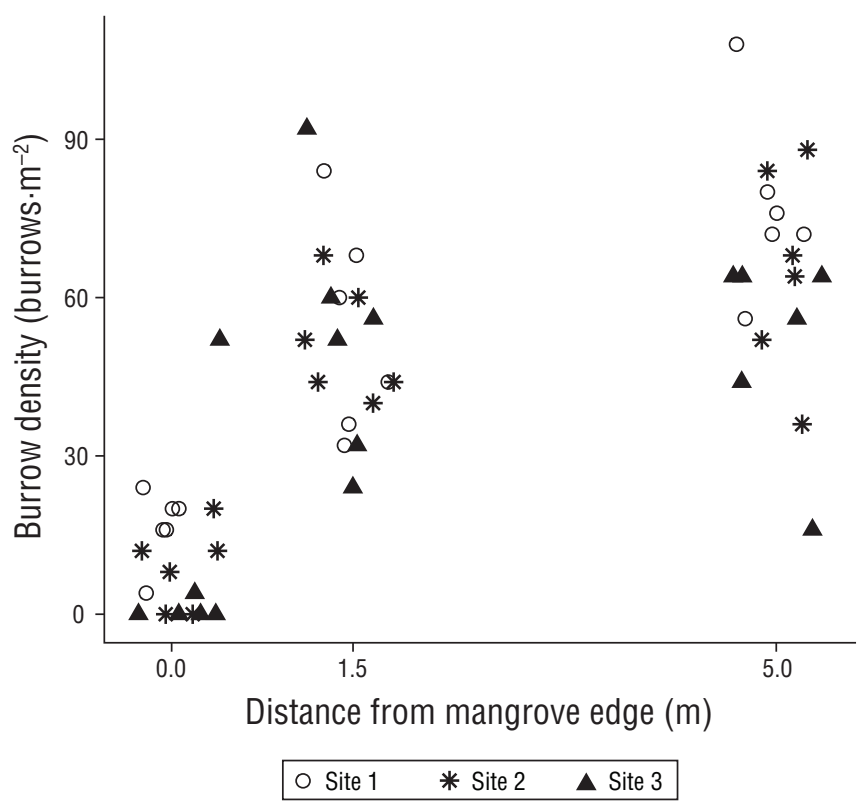

Figure 2. Burrow counts per square meter with distance $(0,1.5$ and $5.0 \mathrm{~m}$ ) from the mangrove edge at the 3 study sites. Points were jittered at each discrete distance to improve visibility.

Figura 2. Conteo de madrigueras por metro cuadrado de acuerdo con la distancia $(0,1.5$ y $5.0 \mathrm{~m})$ del borde del manglar en los 3 sitios de estudio. Se les añadió un desplazamiento a los puntos en cada distancia discreta para mejorar la visibilidad.

\section{Experimento de eliminación de escombros}

Para determinar si la cobertura de escombros bentónicos es un factor que afecta la distribución de las madrigueras de camarones/góbidos, manipulamos los escombros debajo del borde del manglar. Después de la evaluación inicial de la densidad de las madrigueras y el porcentaje de cobertura de todo el material, retiramos los escombros sueltos o adheridos (principalmente hojas y algas) dentro de un cuadrante de $0.25 \mathrm{~m}^{2}$ en 3 parcelas a lo largo de los transectos $(0,10 \mathrm{y}$ $20 \mathrm{~m}$ ) en los 3 sitios. El material adicional que se acumuló en las parcelas se limpió cada 2 días durante un periodo de 2 semanas. Después de 2 semanas de mantener las parcelas despejadas, se volvió a evaluar la densidad de las madrigueras. Evaluamos los efectos del tiempo (antes y después de la eliminación de escombros) y el sitio como factores fijos y su interacción utilizando un modelo lineal generalizado con una distribución de Poisson.

\section{RESUltados}

La distancia a los manglares está asociada con una menor cobertura de escombros y una mayor densidad de madrigueras

Encontramos densidades de madrigueras de camarones/ góbidos $\sim 4 \times$ más bajas debajo del borde del manglar en comparación con las densidades en cualquiera de las 2 distancias en la planicie arenosa adyacente (Fig. 2, Tabla 1; prueba de Tukey $P<0.0001$ para ambas distancias en la planicie arenosa). Se encontraron 11.6 madrigueras $\cdot \mathrm{m}^{-2}$ debajo del borde del manglar, en comparación con las 52.7 y 64.7 madrigueras $\cdot \mathrm{m}^{-2}$ a 1.5 y $5.0 \mathrm{~m}$ de los manglares, respectivamente (Fig. 2); estas densidades de madrigueras en la planicie arenosa difirieron algo entre sí (prueba de Tukey, $P=0.047$ ). También hubo una diferencia en las densidades de las madrigueras por sitio: el sitio 1 tuvo mayores densidades que el sitio 3 (prueba de Tukey, $P=0.0238$ ) y el sitio 2 presentó densidades intermedias. El patrón del incremento de la densidad de madrigueras con el aumento de la distancia al manglar fue consistente en todos los sitios (sin interacción, Tabla 1).

La cubierta de escombros bentónicos consistió principalmente en hojas caídas, G. salicornia o detritos (esqueletos de coral o rocas). De todas las observaciones de la cobertura de escombros bentónicos, el $48 \%$ fueron hojas de manglar caídas; por lo tanto, la cobertura de escombros bentónicos debajo de los manglares y en las planicies arenosas cercanas se asoció en gran medida con los manglares per se. Además, G. salicornia represento el $28.7 \%$ de la cobertura total de escombros, mientras que los detritos de coral y la "otra" cobertura constituyeron el $21.3 \%$ y el $0.1 \%$ de las observaciones de cobertura de escombros, respectivamente. La densidad de raíces aéreas fue variable y osciló entre una media de 12.7 raíces $\cdot \mathrm{m}^{-2}$ (desviación estándar $[\mathrm{DE}]=8.5$ ) en 
Hansen et al.: Invasive mangroves reduce habitat for Hawai'ian shrimp and goby pairs

Table 1. Results of generalized linear models, with model used and transformations (if needed) indicated in parentheses.

Tabla 1. Resultados de los modelos lineales generalizados, con el modelo utilizado y las transformaciones (si fue necesaria) indicadas entre paréntesis.

(a) Burrow density with distance from mangrove and site (generalized linear model with Poisson distribution)

\begin{tabular}{lcccc}
\hline & d.f. & Residual d.f. & Deviance & $P$ \\
Distance & 2 & 51 & 197.94 & $<0.0001$ \\
Site & 2 & 49 & 7.14 & 0.0282 \\
Distance $\times$ Site & 4 & 45 & 5.74 & 0.2175 \\
& & & & \\
\hline
\end{tabular}

(b) Total percent cover $(\log +1)$ with distance from mangrove and site (generalized linear model with Poisson distribution)

\begin{tabular}{lcccc}
\hline & d.f. & Residual d.f. & $F$ & $P$ \\
Distance & 2 & 51 & 24.81 & $<0.0001$ \\
Site & 2 & 49 & 10.61 & 0.0002 \\
Distance $\times$ Site & 4 & 45 & 1.04 & 0.3994
\end{tabular}

(c) Gracilaria salicornia percent cover (logit) with distance from mangrove and site (generalized linear model with Gaussian distribution)

\begin{tabular}{lcclc}
\hline & d.f. & Residual d.f. & $F$ & $P$ \\
Distance & 2 & 51 & 9.10 & 0.0005 \\
Site & 2 & 49 & 0.25 & 0.7797 \\
Distance $\times$ Site & 4 & 45 & 2.50 & 0.0556
\end{tabular}

(d) Leaf percent cover (logit) with distance from mangrove and site (generalized linear model with Gaussian distribution)

\begin{tabular}{lcclc}
\hline & d.f. & Residual d.f. & $F$ & $P$ \\
Distance & 2 & 51 & 9.10 & 0.0005 \\
Site & 2 & 49 & 0.25 & 0.7797 \\
Distance $\times$ Site & 4 & 45 & 2.50 & 0.0556
\end{tabular}

(e) Effect of debris removal at 3 sites on burrow density (generalized linear model with Poisson distribution)

\begin{tabular}{lcccc}
\hline & d.f. & Residual d.f. & Deviance & $P$ \\
Time & 1 & 16 & 49.24 & $<0.0001$ \\
Site & 2 & 14 & 32.26 & $<0.0001$ \\
Time $\times$ Site & 2 & 12 & 7.09 & 0.0289 \\
\hline
\end{tabular}

$19 \%$ and $13 \%$ at $1.5 \mathrm{~m}$ and $5.0 \mathrm{~m}$ from the mangrove edge, respectively (and no difference between $1.5 \mathrm{~m}$ and $5.0 \mathrm{~m}$; Tukey test, $P=0.312$ ). There was also a significant difference in total cover of benthic debris by site (Table 1); site 3 had greater total debris cover than sites 1 and 2 (Tukey test, $P<0.02$ for both), which were not different from each other (Tukey test, $P=0.9899)$. There was no interaction between distance from the mangroves and site (Table 1). el sitio 2 a 16.7 raíces $\cdot \mathrm{m}^{-2}(\mathrm{DE}=10.3)$ en el sitio $1 \mathrm{y}$ hasta 27.3 raíces $\cdot \mathrm{m}^{-2}(\mathrm{DE}=19.2)$ en el Sitio 3 .

El porcentaje total de cobertura de escombros bentónicos, que podría exceder el $100 \%$ si los tipos de cobertura estuvieran estratificados, fue $\sim 4 \times$ mayor por debajo del borde del manglar en comparación con las planicies arenosas que se encontraban a 1.5 y $5.0 \mathrm{~m}$ de distancia (Fig. 3; pruebas de Tukey, $P<0.0001$ para ambas distancias). La cobertura 
Because G. salicornia is invasive in Hawai ${ }^{i} i$, and the only alga we encountered under or near the mangroves, we compared algal cover separately. We found signficantly $(\sim 4 \times)$ less algal cover at both distances from the mangroves than under the mangrove edge (Fig. 3, Table 1; Tukey tests, $P<$ 0.003 for both), with the 2 sandflat locations not different from each other (Tukey test, $P=0.9586$ ). Algal cover was $20 \%$ under the mangrove edge and $5.5 \%$ and $4.9 \%$ at 1.5 and $5.0 \mathrm{~m}$ away, respectively. There was no difference in cover of the alga by site and no interaction between distance from mangrove and site (Table 1).

On average, the cover of fallen leaves dropped markedly with distance from the mangrove edge $(32.7 \%$ vs $6.2 \%$ and $3.1 \%$ at 1.5 and $5.0 \mathrm{~m}$ away, respectively); however, this was largely due to very high cover of leaves at site 3 (Fig. 3; Table 1, significant interaction between distance and site). Leaf cover was approximately the same at the 2 sandflat distances at all sites (Fig. 3).

Evaluating burrow density and total percent cover in all surveyed quadrats, we found a significant negative relationship between burrow density and total benthic debris cover (Fig. 4; adjusted $R^{2}=0.53, P<0.0001$ ). Burrow density also decreased with increasing $G$. salicornia cover (Fig. 3; adjusted $R^{2}=0.22, P<0.0002$ ) and leaf cover (Fig. 3; adjusted $R^{2}=0.58, P<0.0001$ ) when those cover classes were evaluated separately.

\section{Removal of benthic debris resulted in increased shrimp/ goby burrow density}

Removal of loose and attached debris (primarily leaves and algae), maintained over 2 weeks, substantially increased the number of shrimp/goby burrows under the mangrove edge. The average burrow density across sites was 8.44 per square meter before removal and 39.6 per square meter after removal. However, burrow density increased more dramatically at site 2 (8-fold) than at the other sites (3-fold), explaining the interaction between time (before and after debris removal) and site (Fig. 5, Table 1).

\section{Discussion}

We hypothesized that invasive red mangroves ( $R$. mangle) in Hawai' $i$ create inhospitable conditions for sandflatdwelling obligate pairs of an endemic goby ( $P$. mainlandi) and native shrimp (A. rapax). Our field survey at 3 sites along an island in Kāne'ohe Bay, O'ahu, documented that shrimp/ goby burrow density was at least $4 \times$ lower under the mangrove edge compared to nearby sandflats, which had $4 \times$ less benthic debris. Further, our experiment testing the effects of debris removal under mangroves resulted in large increases in burrow densities after just 2 weeks, indicating that this debris reduces habitat suitability for the native shrimp and goby pairs.

The benthic debris along the mangroves was largely composed of fallen and trapped leaves, which accounted for $58 \%$ de escombros bentónicos alcanzó el 66\% debajo del borde del manglar (75\% de cobertura total con capas) y estaba compuesta por hojas, algas y otros escombros. Las planicies arenosas adyacentes presentaron una cobertura de escombros significativamente menor, con $19 \%$ y $13 \%$ a 1.5 y $5.0 \mathrm{~m}$ del borde del manglar, respectivamente (sin diferencias entre 1.5 y $5.0 \mathrm{~m}$; prueba de Tukey, $P=0.312$ ). También hubo una diferencia significativa en la cobertura total de detritos bentónicos por sitio (Tabla 1); el sitio 3 presentó una mayor cobertura total de escombros que los sitios 1 y 2 (prueba de Tukey, $P<0.02$ para ambos), los cuales no difirieron entre sí (prueba de Tukey, $P=0.9899$ ). No hubo interacción entre la distancia a los manglares y el sitio (Tabla 1).

Debido a que $G$. salicornia es invasora en Hawai' $i$, y que fue la única alga que encontramos debajo o cerca de los manglares, comparamos la cobertura de algas por separado. Encontramos que la cobertura de algas era significativamente $(\sim 4 \times)$ menor en ambas distancias del manglar que debajo del borde del manglar (Fig. 3, Tabla 1; pruebas de Tukey, $P<$ 0.003 para ambos), sin diferencias entre los 2 sitios de planicies arenosas (Prueba de Tukey, $P=0.9586$ ). La cobertura de algas fue $20 \%$ bajo el borde del manglar y $5.5 \%$ y $4.9 \%$ a 1.5 y $5.0 \mathrm{~m}$ de distancia, respectivamente. No hubo diferencia en la cobertura del alga por sitio y no hubo interacción entre la distancia al manglar y el sitio (Tabla 1).

En promedio, la cobertura de hojas caídas se redujo notablemente con la distancia al borde del manglar (32.7\% vs $6.2 \%$ y $3.1 \%$ a 1.5 y $5.0 \mathrm{~m}$ de distancia, respectivamente); $\sin$ embargo, esto se debió en gran parte a la cobertura de hojas en el sitio 3, que fue muy alta (Fig. 3; Tabla 1, interacción significativa entre la distancia y el sitio). La cobertura de las hojas fue aproximadamente la misma a las 2 distancias sobre las planicies arenosas en todos los sitios (Fig. 3).

Al evaluar la densidad de madrigueras y el porcentaje de cobertura total en todos los cuadrantes muestreados, encontramos una relación negativa significativa entre la densidad de madrigueras y la cobertura total de escombros bentónicos (Fig. $4 ; R^{2}$ ajustado $=0.53, P<0.0001$ ). La densidad de madrigueras también disminuyó conforme aumentó la cobertura de G. salicornia (Fig. 3; $R^{2}$ ajustado $=0.22, P<$ 0.0002 ) y la cobertura de hojas (Fig. $3 ; R^{2}$ ajustado $=0.58$, $P<0.0001)$ cuando esas clases de cobertura se evaluaron por separado.

\section{La eliminación de desechos bentónicos dio como resultado una mayor densidad de madrigueras de camarones/ góbidos}

La eliminación de escombros sueltos y adheridos (principalmente hojas y algas), que se realizó de manera continua por 2 semanas, incrementó sustancialmente el número de madrigueras de camarones/góbidos debajo del borde del manglar. La densidad promedio de madrigueras en todos los sitios fue de 8.44 por metro cuadrado antes de la eliminación y de 39.6 por metro cuadrado después de la eliminación. Sin 
of the variation in shrimp/goby burrowing density across sites and distances from the mangrove. Further, as our initial observations suggested, the mangrove roots trap drift G. salicornia and also provide surfaces onto which the alga attaches. While a small amount ( $\sim 5 \%$ cover $)$ of this invasive red alga was found on the sandflats at both 1.5 and $5.0 \mathrm{~m}$ from the mangrove edge, much more (average of 20\% cover) was present under the mangrove edge. We sometimes found accumulation of leaves and algae together, the combination of which created a thick mat on the benthos. The mangrove prop roots themselves also may have inhibited burrowing, as lower burrow densities were found at site 3, where mangrove root counts ranked highest (although variability was quite high). As the accumulation of leaves was also significantly greater at site 3, we suspect that the cover of leaves was a greater deterrent to burrowing than the prop roots; however, more prop roots may trap more leaves, making the 2 potential controlling factors difficult to disentangle.

Our survey and the rapid increase in burrowing densities following experimental removal of debris beneath mangrove roots provide clear evidence that material covering the embargo, la densidad de las madrigueras aumentó más drásticamente en el sitio 2 ( 8 veces más alta) que en los otros sitios (3 veces más alta), lo que explica la interacción entre el tiempo (antes y después de la eliminación de escombros) y el sitio (Fig. 5, Tabla 1).

\section{Discusıón}

Planteamos la hipótesis de que los manglares rojos invasores ( $R$. mangle) en Hawai'i crean condiciones inhóspitas para los pares obligados de un góbido endémico (P. mainlandi) y un camarón nativo (A. rapax) que habitan en las planicies arenosas. Nuestro estudio de campo en 3 sitios a lo largo de una isla en la bahía de Kāne'ohe, O`ahu, documentó que la densidad de las madrigueras de camarones/ góbidos era al menos $4 \times$ menor debajo del borde del manglar en comparación con la de las planicies arenosas cercanas, que tenían $4 \times$ menos detritos bentónicos. Además, nuestro experimento para investigar los efectos de la eliminación de escombros debajo de los manglares dio como resultado grandes aumentos en la densidad de las madrigueras después
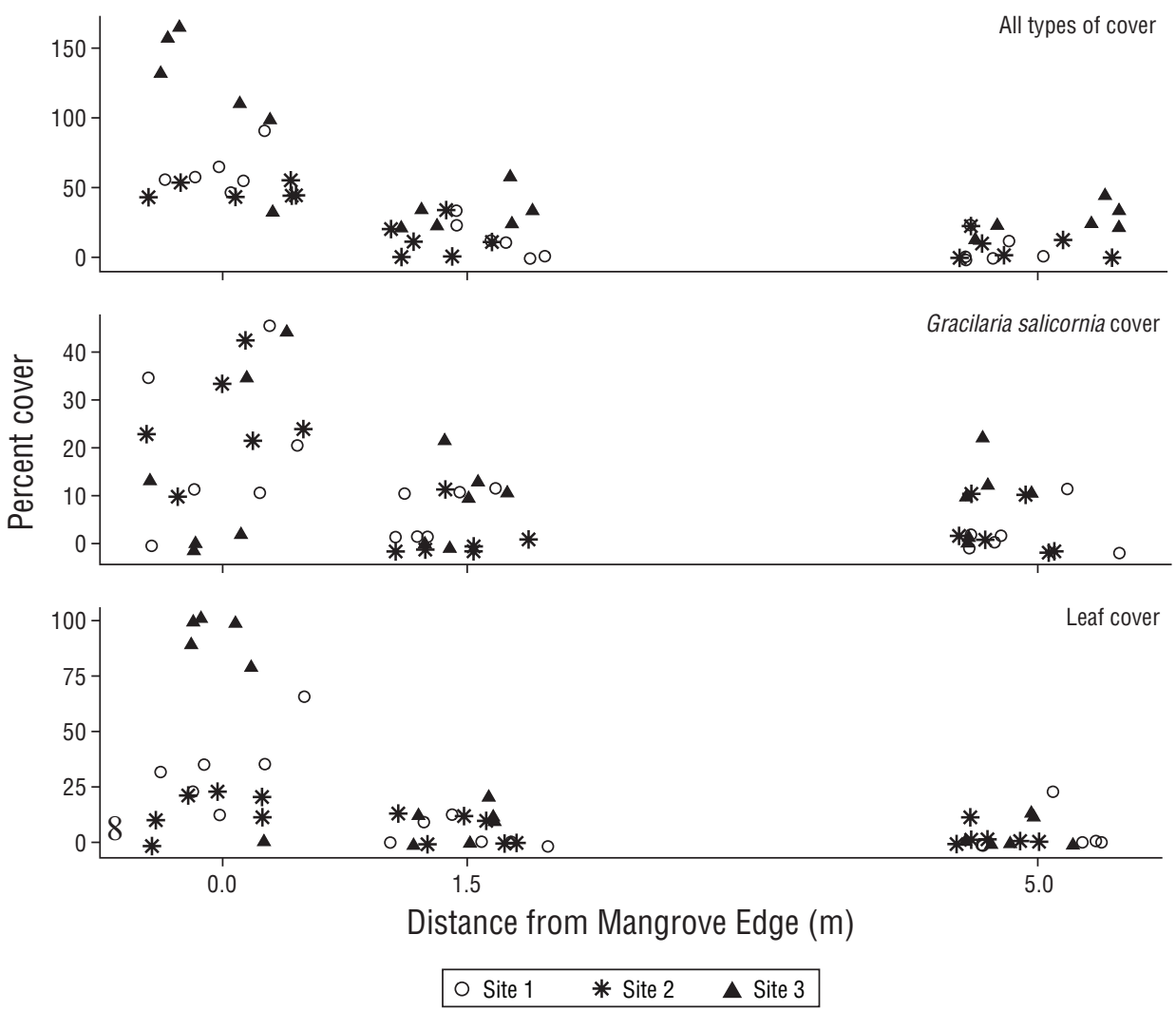

Figure 3. Total cover of benthic debris, as well as the subsets of Gracilaria salicornia cover and leaf cover, with distance (0, 1.5 and $5.0 \mathrm{~m})$ from the mangrove edge at the 3 study sites. Points were jittered at each discrete distance to improve visibility.

Figura 3. Cobertura total de los escombros bentónicos, así como los subconjuntos de la cobertura de Gracilaria salicornia y la cobertura de hojas, con la distancia $(0,1.5$ y 5.0 m) al borde del manglar en los 3 sitios de estudio. Se les añadió un desplazamiento a los puntos en cada distancia discreta para mejorar la visibilidad. 


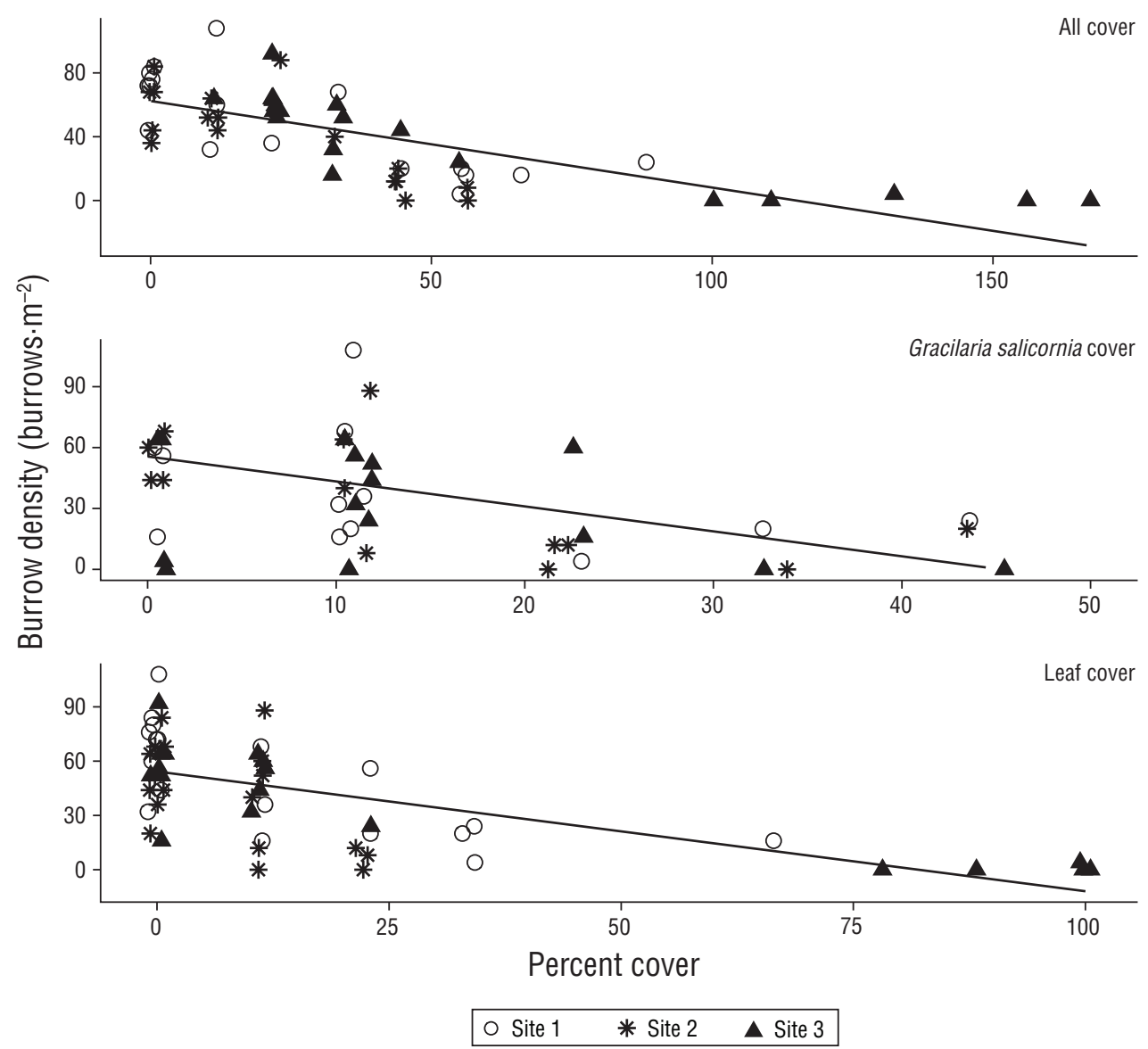

Figure 4. Relationship between the total cover of debris (all debris cover types can lead to $>100 \%$ due to layering), Gracilaria salicornia cover, or leaf cover and burrow density across the 3 sites. Points were jittered at each discrete distance to improve visibility. Lines indicate significant linear regressions.

Figura 4. Relación entre la cobertura total de escombros (todos los tipos de cobertura de escombros pueden dar lugar a $>100 \%$ debido a la formación de capas), la cobertura de Gracilaria salicornia o la cobertura de hojas y la densidad de las madrigueras en los 3 sitios. Los puntos se desplazaron en cada distancia discreta para mejorar la visibilidad. Las líneas indican regresiones lineales significativas.

sandflats has negative effects on shrimp/goby burrowing. Other studies have found these same shrimp/goby pairs to be deterred by cover over the benthos; sandflat invasion of the alga Halimeda kanaloana is associated with much lower densities of these mutualist burrow-dwellers (Fukunaga 2008, Langston and Spalding 2017). In our experiment, nearby shrimp were apparently able to quickly perceive and colonize newly available habitat upon debris removal, despite their poor eyesight (Zeng and Jaafar 2012). Beyond that, we can only speculate as to the role that debris plays in shrimp/goby presence; as the goby uses visual cues to detect potential predators and warn the shrimp, surface debris may impede this communication system and reduce the likelihood of the shrimp venturing away from the burrow for foraging (Nelson 2005).

Since we found a small but significant increase in the number of shrimp/goby burrows as we moved from $1.5 \mathrm{~m}$ to $5.0 \mathrm{~m}$ from the mangrove edge, without a significant decrease in debris covering the sediment over the same distance, there de solo 2 semanas, lo que indica que estos escombros reducen la idoneidad del hábitat para las parejas nativas de camarones y góbidos.

Los escombros bentónicos a lo largo de los manglares estaban compuestos en gran parte por hojas caídas y atrapadas, las cuales explicaron el $58 \%$ de la variación en la densidad de las madrigueras de camarones/góbidos en todos los sitios y las distancias al manglar. Además, como lo sugirieron nuestras observaciones iniciales, las raíces de los manglares atrapan G. salicornia a la deriva y también proporcionan superficies a las cuales se adhiere el alga. Si bien se encontró una pequeña cantidad $(\sim 5 \%$ de cobertura) de esta alga roja invasora en las planicies arenosas a 1.5 y $5.0 \mathrm{~m}$ del borde del manglar, se encontró mucha más (un promedio del $20 \%$ de cobertura) debajo del borde del manglar. A veces encontramos acumulaciones de hojas y algas juntas, cuya combinación creaba un manto grueso sobre el bentos. Las raíces aéreas de los manglares también pueden haber inhibido el establecimiento de madrigueras, 
may be effects of the mangroves that extend beyond their physical presence and associated debris coverage. These mangroves are known to change the chemical properties of sediment, with fallen leaves leaching tannins and leading to organic carbon accumulation and decomposition that reduces dissolved oxygen and increases hydrogen sulfide concentrations (Demopoulos and Smith 2010). It may be that such physicochemical changes somewhat reduce suitability for shrimp/goby pairs near (at least within $1.5 \mathrm{~m}$ of) the mangrove edge. Food quality may also be reduced near the mangroves; a previous study found that red mangrove detritus contributes little to the diet of native detritivores in Hawai' $i$, unlike in the mangrove's native range, where organisms have evolved the ability to digest these materials (Demopoulos et al. 2007).

Our finding that invasive G. salicornia is associated with mangroves at our study site is troubling considering that this species can be harmful to coral reefs through overgrowth and drawdown of oxygen, negatively affecting coral reef organisms (Smith et al. 2004, Martinez et al. 2012). Hawai'ian coral reefs support many fishes and other organisms that contribute to the local economy, with a value over $\$ 3.5$ billion

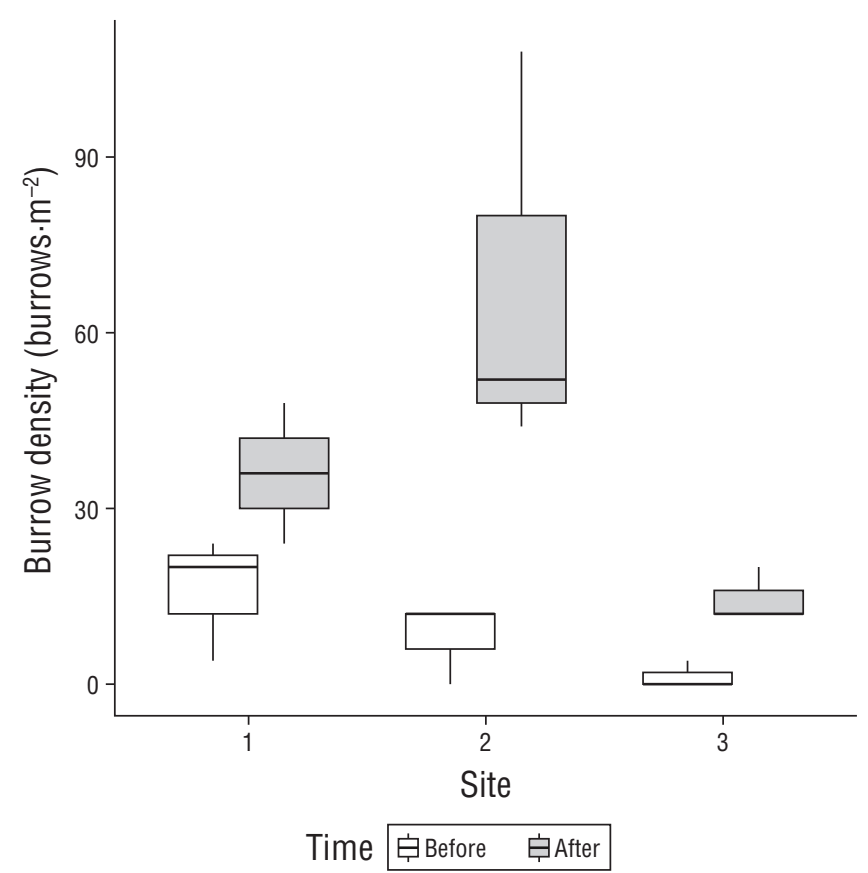

Figure 5. Burrow counts before and after removal of debris (primarily leaves and algae). Dark horizontal line indicates median, while vertical line shows distribution of data. The box indicates the interquartile range between the 25th and 75th percentiles.

Figura 5. Conteo de las madrigueras antes y después de la eliminación de escombros (principalmente hojas y algas). Las líneas horizontales oscuras indican la mediana, mientras que las líneas verticales muestran la distribución de los datos. El cuadro indica el rango intercuartílico entre los percentiles 25 y 75 . ya que se encontraron densidades de madrigueras más bajas en el sitio 3, donde el conteo de raíces de manglar fue el más alto (aunque la variabilidad fue bastante alta). Como la acumulación de hojas también fue significativamente mayor en el sitio 3, suponemos que la cobertura de hojas fue un mayor impedimento para el establecimiento de madrigueras que las raíces aéreas; sin embargo, una mayor cantidad de raíces aéreas puede atrapar una mayor cantidad de hojas, ocasionando que los 2 factores de control potenciales sean difíciles de desasociar.

Nuestro estudio y el rápido aumento de las densidades de madrigueras después de la eliminación experimental de los escombros por debajo de las raíces de los manglares proporcionan una clara evidencia de que el material que cubre las planicies arenosas tiene efectos negativos sobre el establecimiento de las madrigueras de camarones/góbidos. Otros estudios han encontrado que estas mismas parejas de camarón/ góbido son obstruidas por las coberturas sobre el bentos; la invasión del alga Halimeda kanaloana en las planicies arenosas se asocia con densidades mucho más bajas de estos habitantes de madrigueras mutualistas (Fukunaga 2008, Langston y Spalding 2017). En nuestro experimento, los camarones cercanos aparentemente pudieron percibir y colonizar rápidamente el hábitat nuevo disponible después de la eliminación de los escombros, a pesar de su visión deficiente (Zeng y Jaafar 2012). Más allá de eso, solo podemos especular sobre el papel que juegan los escombros en la presencia de los camarones/góbidos; como el góbido utiliza señales visuales para detectar depredadores potenciales y advertir al camarón, los escombros en la superficie pueden obstaculizar este sistema de comunicación y reducir la probabilidad de que el camarón se aventure lejos de la madriguera para buscar alimento (Nelson 2005).

Debido a que encontramos un aumento pequeño pero significativo en el número de madrigueras de camarones/ góbidos conforme nos movimos de 1.5 a $5.0 \mathrm{~m}$ desde el borde del manglar, sin una disminución significativa en los escombros que cubren el sedimento en la misma distancia, pueden haber efectos de los manglares que se extienden más allá de su presencia física y la cobertura de escombros asociada. Se sabe que estos manglares cambian las propiedades químicas de los sedimentos, ya que las hojas caídas lixivian taninos y conducen a la acumulación y descomposición del carbono orgánico que reduce el oxígeno disuelto y aumenta las concentraciones de sulfuro de hidrógeno (Demopoulos y Smith 2010). Puede ser que tales cambios fisicoquímicos reduzcan en cierta medida la idoneidad para las parejas de camarones/góbidos cerca (por lo menos a una distancia $\leq 1.5 \mathrm{~m}$ ) del borde del manglar. La calidad de los alimentos también puede verse reducida cerca de los manglares; un estudio anterior encontró que los detritos del mangle rojo contribuyen poco a la dieta de los detritívoros nativos en Hawai ${ }^{i}$, a diferencia de lo observado en la distribución nativa del manglar, donde los organismos 
US dollars (Bishop et al. 2011). Kāne'ohe Bay corals have been recognized for high resiliency to bleaching and thus are being used as models for other regions to aid in understanding of this phenomenon (Jury and Toonen 2019). This G. salicornia does not invade new regions easily; rather, it has been observed to primarily spread very locally through fragmentation after it was intentionally introduced to several locations in the islands for aquaculture studies (Smith et al. 2002). Nonetheless, care should be taken to minimize further spread.

As with most invaders, red mangroves have both positive and negative effects, which must be weighed by managers in the context of ecological, social, and financial perspectives/ constraints. Positive effects include protection of coral reefs by trapping land-derived sediments (D'iorio 2003) and provision of habitat to some native (and to non-native) fishes (MacKenzie and Kryss 2013, Goecke and Carstenn 2017), which many experience reduced risk of predation through prop root structural complexity (Nagelkerken 2009). Mangroves in Hawai' $i$ also convert and store substantial amounts of atmospheric carbon in live tissues and detritus and accrete sediments along shores, both of which can serve to mitigate climate change impacts (Soper et al. 2019). In contrast, negative effects include displacing endangered native bird habitat (Allen 1998) and altering nearshore invertebrate community composition and food web structure while facilitating numerous non-native invertebrate species (Demopoulos et al. 2007, Demopoulos and Smith 2010). Invasion of fishponds, which are highly valued cultural resources to native Hawai'ians (Bremer et al. 2018), results in mangroves growing directly into and degrading the containment walls (Chimner et al. 2006). To this list of negative effects, our research adds that invasive red mangroves in Hawai' $i$ displace habitat utilized by 2 native (one endemic) sandflat species through increased benthic debris cover, including cover of an invasive alga.

In conclusion, although this project was limited in spatial scope, we posit that red mangroves are likely to have similar negative effects on this mutualistic shrimp and goby interaction elsewhere within their widespread distribution in the Hawai'ian archipelago. A high degree of detritus accumulation documented in Hawai' ian red mangrove stands relative to other regions (Cox and Allen 1999) reinforces our expectation that similar negative effects could occur in other locations in the islands. Although our study focused only along the edge of mangrove stands, these mangroves can cover hectares of sandflat, presumably displacing shrimp/goby pairs throughout their footprint. Further, where G. salicornia has been introduced, it may add to the negative effects of mangroves on shrimp/goby burrowing through prop root trapping and attachment to the roots. While acknowledging potential benefits of invasive mangroves for shoreline protection and habitat for some fishes in Hawai ' $i$, current efforts to remove mangroves to restore natural and cultural values would also help reverse negative impacts to the endemic goby and native shrimp pairs studied here. han desarrollado la capacidad de digerir estos materiales (Demopoulos et al. 2007).

Nuestro hallazgo de que la especie invasora G. salicornia está asociada con los manglares en nuestro sitio de estudio es preocupante considerando que esta especie puede ser dañina para los arrecifes de coral por medio del crecimiento excesivo y la reducción de oxígeno, afectando negativamente a los organismos de los arrecifes de coral (Smith et al. 2004, Martinez et al. 2012). Los arrecifes de coral de Hawai'i sustentan muchos peces y otros organismos que contribuyen a la economía local, con un valor de más de \$3.5 mil millones de dólares estadounidenses (Bishop et al. 2011). Los corales de la bahía de Kāne'ohe son reconocidos por su alta resistencia al blanqueamiento y, por lo tanto, se están utilizando como modelos para otras regiones para ayudar a comprender este fenómeno (Jury y Toonen 2019). Esta G. salicornia no invade nuevas regiones fácilmente; más bien, se ha observado que se propaga principalmente de manera muy local por la fragmentación después de su introducción intencional en varios lugares de las islas para realizar estudios de acuacultura (Smith et al. 2002). No obstante, se deben tomar medidas para minimizar la extensión de su propagación en el futuro.

Como ocurre con la mayoría de los invasores, los manglares rojos tienen efectos tanto positivos como negativos, los cuales deben ser ponderados por los gestores en el contexto de las perspectivas/limitaciones ecológicas, sociales y financieras. Los efectos positivos incluyen la protección de los arrecifes de coral al atrapar sedimentos terrestres (D'iorio 2003) y la provisión de hábitat para algunos peces nativos (y no nativos) (MacKenzie y Kryss 2013, Goecke y Carstenn 2017), muchos de los cuales experimentan una reducción en el riesgo de depredación debido a la complejidad estructural de las raíces aéreas (Nagelkerken 2009). Los manglares de Hawai' $i$ también convierten y almacenan cantidades sustanciales de carbono atmosférico en tejidos vivos y detritos y acumulan sedimentos a lo largo de las costas, lo que puede servir para mitigar los impactos del cambio climático (Soper et al. 2019). Por el contrario, los efectos negativos incluyen el desplazamiento del hábitat de aves nativas en peligro de extinción (Allen 1998) y la alteración de la composición de la comunidad de invertebrados cercanos a la costa y la estructura de la red alimentaria mientras que se favorece el estabelecimiento de numerosas especies de invertebrados no nativos (Demopoulos et al. 2007, Demopoulos y Smith 2010). La invasión de los estanques de peces, que son recursos culturales muy valorados por los nativos de Hawai'i (Bremer et al. 2018), ocasiona que los manglares crezcan directamente en los muros de contención y los degraden (Chimner et al. 2006). A esta lista de efectos negativos, nuestra investigación agrega que los manglares rojos invasores en Hawai' $i$ desplazan el hábitat utilizado por 2 especies nativas (una endémica) de las planicies arenosas por medio de una mayor cobertura de escombros bentónicos, incluida la cobertura de un alga invasora. 
Hansen et al.: Invasive mangroves reduce habitat for Hawai'ian shrimp and goby pairs

\section{ACKNOWLEDGMENTS}

We thank Michael Izumiyama, Christian Tettelbach, Tyler Phelps, David Bell, Melissa Patten, Laura Burrus, and Karina Nielsen for their assistance in implementation of the inaugural Diving into Ecology and Evolution Program (DEEP) marine immersion semester at San Francisco State University, and the other DEEP students who assisted and supported $\mathrm{MH}$ in the field. We are grateful to Judy Lemus, Jason Jones, Kawika Winter, and Fred Reppun for logistical assistance and for stimulating and supporting our research at the Hawai' $i$ Institute of Marine Biology. Funding for the DEEP semester was provided by the Seagrass Resiliency Project of KEB.

\section{REFERENCES}

Allen JA. 1998. Mangroves as alien species: the case of Hawaii. Global Ecol Biogeogr Lett. 7(1):61-71. https://doi.org/10.2307/2997698

Bishop RC, Chapman DJ, Kanninen BJ, Krosnick JA, Leeworthy B, Meade NF. 2011. Total economic value for protecting and restoring Hawaiian coral reef ecosystems: final report. Silver Spring (MD): NOAA Office of National Marine Sanctuaries, Office of Response and Restoration, and Coral Reef Conservation Program.

https://www.coris.noaa.gov/activities/hawaii_econeval/ welcome.html

Blackburn TM, Essl F, Evans T, Hulme PE, Jeschke JM, Kühn I, Kumschick S, Marková Z, Mrugała A, Nentwig W, et al. 2014. A unified classification of alien species based on the magnitude of their environmental impacts. PLOS Biol. 12(5):e1001850. https://doi.org/10.1371/journal.pbio.1001850

Bremer L, Falinski K, Ching C, Wada CA, Burnett KM, KukeaShultz K, Reppun N, Chun G, Oleson KLL, Ticktin T. 2018. Biocultural restoration of traditional agriculture: cultural, environmental, and economic outcomes of Lo'i Kalo restoration in He'eia, O‘ahu. Sustainability. 10(12):4502. https://doi.org/10.3390/su10124502

Chimner RA, Fry B, Kaneshiro MY, Cormier N. 2006. Current extent and historical expansion of introduced mangroves on O'ahu, Hawai'i. Pac Sci. 60(3):377-384. https://doi.org/10.1353/psc.2006.0013

Cox EF, Allen JA. 1999. Stand structure and productivity of the introduced Rhizophora mangle in Hawaii. Estuaries. 22(2):276. https://doi.org/10.2307/1352983

Demopoulos AWJ, Fry B, Smith CR. 2007. Food web structure in exotic and native mangroves: a Hawaii-Puerto Rico comparison. Oecologia. 153(3):675-686. https://doi.org/10.1007/s00442-007-0751-x

Demopoulos AWJ, Smith CR. 2010. Invasive mangroves alter macrofaunal community structure and facilitate opportunistic exotics. Mar Ecol Prog Ser. 404:51-67. https://doi.org/10.3354/meps08483

Devaney DM, Kelly M, Lee PJ, Motteler LS. 1982. Kane'ohe. A History of Change. Honolulu (HI): Bess Press.

D'iorio MM. 2003. Mangroves and shoreline change on Molokai, Hawaii: assessing the role of introduced Rhizophora mangle in sediment dynamics and coastal change using remote sensing and GIS [dissertation]. [Santa Cruz (CA)]: University of California.
En conclusión, aunque este proyecto tenía un alcance espacial limitado, planteamos que es probable que los manglares rojos tengan efectos negativos similares sobre esta interacción mutualista de camarones y góbidos en otras partes de su amplia distribución en el archipiélago hawaiano. Un alto grado de acumulación de detritos documentado en los rodales de manglar rojo de Hawai'i en relación con otras regiones (Cox y Allen 1999) refuerza nuestra expectativa de que pueden ocurrir efectos negativos similares en otros sitios de las islas. Aunque nuestro estudio se centró solo a lo largo del borde de los rodales de manglares, estos manglares pueden cubrir hectáreas de planicies arenosas, presumiblemente desplazando a las parejas de camarones/góbidos en toda su extensión. Además, en los lugares en los que se ha introducido G. salicornia, esta puede aumentar los efectos negativos de los manglares sobre las madrigueras de los camarones/ góbidos al ser atrapada por las raíces aéreas y al unirse a las raíces. Aunque se reconocen los beneficios potenciales de los manglares invasores para la protección de la costa y el hábitat de algunos peces en Hawai'i, los esfuerzos actuales para eliminar los manglares para restaurar los valores naturales y culturales también ayudarían a revertir los impactos negativos en las parejas del góbido endémico y el camarón nativo estudiadas aquí.

\section{Agradecimientos}

Agradecemos a Michael Izumiyama, Christian Tettelbach, Tyler Phelps, David Bell, Melissa Patten, Laura Burrus y Karina Nielsen su ayuda en la implementación del semestre inaugural de inmersión marina del Diving into Ecology and Evolution Program (DEEP) en la Universidad Estatal de San Francisco, y a los otros estudiantes de DEEP que ayudaron y apoyaron a MH en el campo. Agradecemos a Judy Lemus, Jason Jones, Kawika Winter y Fred Reppun por asistir logística y por estimular y apoyar nuestra investigación en el Instituto de Biología Marina de Hawai'i. El financiamiento para el semestre DEEP fue proporcionado por el Seagrass Resiliency Projec de KEB.

Traducido al español por Claudia Michel-Villalobos.

Fukunaga A. 2008. Invertebrate community associated with the macroalga Halimeda kanaloana meadow in Maui, Hawaii. Internat Rev Hydrobiol. 93(3):328-341. https://doi.org/10.1002/iroh.200711063

Goecke SD, Carstenn SM. 2017. Fish communities and juvenile habitat associated with non-native Rhizophora mangle L. in Hawai‘i. Hydrobiologia. 803(1):209-224. https://doi.org/10.1007/s10750-017-3182-7

Hoover JP. 2016. Hawaiian Reef Fishes: Sea Turtles, Dolphins, Whales, and Seals. Honolulu (HI): Mutual Publishing.

Hothorn T, Bretz F, Westfall P. 2008. Simultaneous inference in general parametric models. Biometrical J. 50(3):346-363. https://doi.org/10.1002/bimj.200810425 
Jeschke JM, Bacher S, Blackburn TM, Dick JTA, Essl F, Evans T, Gaertner M, Hulme PE, Kühn I, Mrugała A, et al. 2014. Defining the impact of non-native species. Conserv Biol. 28(5):1188-1194. https://doi.org/10.1111/cobi.12299

Jury CP, Toonen RJ. 2019. Adaptive responses and local stressor mitigation drive coral resilience in warmer, more acidic oceans. Proc R Soc B. 286(1902):20190614. https://doi.org/10.1098/rspb.2019.0614

Karl JW, Karl MG "Sherm," McCord SE, Kachergis E. 2016. Critical evaluations of vegetation cover measurement techniques: a response to Thacker et al. (2015). Rangelands. 38(5):297-300. https://doi.org/10.1016/j.rala.2016.08.005

Karplus I, Thompson A. 2011. The partnership between gobiid fishes and burrowing alpheid shrimps. In: Kapoor B (ed.). The Biology of Gobies. Boca Raton (FL): Science Publishers; [accessed 2020 May 26]. http://www.crenetbase.com/ https://doi.org/10.1201/b11397-29. p. 559-607.

Kumschick S, Gaertner M, Vilà M, Essl F, Jeschke JM, Pyšek P, Ricciardi A, Bacher S, Blackburn TM, Dick JTA, et al. 2015. Ecological impacts of alien species: quantification, scope, caveats, and recommendations. BioScience. 65(1):55-63. https://doi.org/10.1093/biosci/biu193

Langston RC, Spalding HL. 2017. A survey of fishes associated with Hawaiian deep-water Halimeda kanaloana (Bryopsidales: Halimedaceae) and Avrainvillea sp. (Bryopsidales: Udoteaceae) meadows. PeerJ. 5:e3307. https://doi.org/10.7717/peerj.3307

Larned ST. 1998. Nitrogen- versus phosphorus-limited growth and sources of nutrients for coral reef macroalgae. Mar Biol. 132(3):409-421. https://doi.org/10.1007/s002270050407

Lyons PJ. 2013. The benefit of obligate versus facultative strategies in a shrimp-goby mutualism. Behav Ecol Sociobiol. 67(5):737-745. https://doi.org/10.1007/s00265-013-1497-6

MacKenzie R, Kryss CL. 2013. Impacts of exotic mangroves and chemical eradication of mangroves on tide pool fish assemblages. Mar Ecol Prog Ser. 472:219-237. https://doi.org/10.3354/meps09961

Martinez JA, Smith CM, Richmond RH. 2012. Invasive algal mats degrade coral reef physical habitat quality. Estuar Coast Shelf S. 99:42-49. https://doi.org/10.1016/j.ecss.2011.12.022

Molnar JL, Gamboa RL, Revenga C, Spalding MD. 2008. Assessing the global threat of invasive species to marine biodiversity. Front Ecol Environ. 6(9):485-492. https://doi.org/10.1890/070064

Nagelkerken I. 2009. Evaluation of nursery function of mangroves and seagrass beds for tropical decapods and reef fishes: Patterns and underlying mechanisms. In: Nagelkerken I (ed.). Ecological Connectivity among Tropical Coastal Ecosystems. Dordrecht: Springer Netherlands; [accessed 2020 May 26]. p. 357-399. http://link.springer. com/10.1007/978-90-481-2406-0_10.
Nakahara BA. 2007. Utilization of mangrove habitat by megafauna along the southern coast of Molokai, Hawaii [dissertation]. Hawaii: University of Hawaii.

Nelson RP. 2005. A behavioral study of the Hawai'ian goby-shrimp relationship and the effects predation on the system [MSc thesis]. [Manoa (HI)]: University of Hawaii. http://hdl.handle. net/10125/10554.

Nelson SG, Glenn EP, Moore D, Ambrose B. 2009. Growth and distribution of the macroalgae Gracilaria salicornia and G. parvispora (Rhodophyta) established from aquaculture introductions at Moloka'i, Hawai'i. Pacific Science. 63(3):383-396. https://doi.org/10.2984/049.063.0307

Parker IM, Simberloff D, Lonsdale WM, Goodell K, Wonham M, Kareiva PM, Williamson MH, Holle BV, Moyle PB, Byers JE, et al. 1999. Impact: toward a framework for understanding the ecological effects of invaders. Biological Invasions. 1(1):3-19.

R Core Team. 2020. R: A language and environment for statistical computing. Vienna (Austria): R Foundation for Statistical Computing. https://www.R-project.org/.

Ricciardi A. 2007. Are modern biological invasions an unprecedented form of global change? $=$ ¿Las invasiones biológicas modernas son una forma de cambio global sin precedente? Conserv Biol. 21(2):329-336. https://doi.org/10.1111/j.1523-1739.2006.00615.x

Richardson DM, Pysek P, Rejmanek M, Barbour MG, Panetta FD, West CJ. 2000. Naturalization and invasion of alien plants: concepts and definitions. Divers Distrib. 6(2):93-107. https:// doi.org/10.1046/j.1472-4642.2000.00083.x

Simberloff D. 2011. How common are invasion-induced ecosystem impacts? Biol Invasions. 13(5):1255-1268. https://doi.org/10.1007/s10530-011-9956-3

Smith JE, Hunter CL, Conklin EJ, Most R, Sauvage T, Squair C, Smith CM. 2004. Ecology of the invasive red alga Gracilaria salicornia (Rhodophyta) on O'ahu, Hawai'i. Pac Sci. 58(2):325-343. https://doi.org/10.1353/psc.2004.0023

Smith JE, Hunter CL, Smith CM. 2002. Distribution and reproductive characteristics of nonindigenous and invasive marine algae in the Hawaiian islands. Pac Sci. 56(3):299-315. https://doi.org/10.1353/psc.2002.0030

Soper FM, MacKenzie RA, Sharma S, Cole TG, Litton CM, Sparks JP. 2019. Non-native mangroves support carbon storage, sediment carbon burial, and accretion of coastal ecosystems. Glob Change Biol. 25(12):4315-4326. https://doi.org/10.1111/gcb.14813

Walsh GE. 1967. An ecological study of a Hawaiian mangrove swamp. Estuaries. 83:420-431.

Williams SL, Smith JE. 2007. A global review of the distribution, taxonomy, and impacts of introduced seaweeds. Annu Rev Ecol Evol Syst. 38(1):327-359. https://doi.org/10.1146/annurev.ecolsys.38.091206.095543

Zeng Y, Jaafar Z. 2012. Visual acuity of the goby-associated shrimp, Alpheus rapax Fabricius, 1798 (Decapoda, Alpheidae). Crustaceana. 85(12-13):1487-1497. https://doi.org/10.1163/15685403-00003128

Received July 2020, accepted September 2020. 